\title{
RAD NA SIGURAN NAČIN U SKUČENIM PROSTORIMA
}

\author{
Kristina Dundović \\ Dipl. ing., predavač, Veleučilište u Rijeci, Vukovarska 58, 51000 Rijeka, Hrvatska; \\ e-mail:kdundovic@veleri.hr
}

\section{Stela Stašić}

Struč. spec. ing. sec., Viktor Lenac d. d., Martinšćica bb, p. p. 210, 51000 Rijeka, Hrvatska; e-mail: stelastasic@gmail.com

\section{SAŽETAK}

Skučeni prostor može se definirati kao prostor koji je dovoljno velik da radnik u njega može u potpunosti ući i obaviti posao, nije dizajniran za stalan boravak radnika i ima ograničenja pri ulasku ili izlasku. Najveće opasnosti u skučenim prostorima povezane su s atmosferskim uvjetima tih prostora. Atmosfera unutar različitih skučenih prostora ovisi o vrsti prostora, radovima koji se odvijaju unutar njega i onome što je u njima ranije bilo pohranjeno. Najučestalije opasnosti u skučenim prostorima su opasnost od gušenja, opasnost od požara i/ili eksplozije i opasnost od trovanja. Rad u skučenim prostorima predstavlja visokorizičnu aktivnost stoga je provođenje mjera zaštite na radu od ključne važnosti za očuvanje zdravlja i sigurnosti svih radnika koji ulaze i rade u takvim prostorima. Surha ovog rada je istražiti i analizirati opasnosti i štetnosti povezane s radom u skučenim prostorima. Cilj rada je teorijski prikazati i opisati mjere i postupke za rad na siguran način u skučenim prostorima.

Ključne riječi: mjere zaštite, opasnosti, skučeni prostor

\section{UVOD}

Rad u skučenom prostoru spada pod visokorizičnu aktivnost i predstavlja značajnu opasnost kako za radnike tako i za osobe zadužene za evakuaciju i spašavanje u hitnim slučajevima. Rizici prilikom rada u skučenim prostorima mogu biti izuzetno visoki. Atmosferski uvjeti su vodeći uzrok nesreća i smrtnih slučajeva u skučenim prostorima.

Skučeni prostori predstavljaju opasnost jer obično nisu dizajnirani kao prostori u kojima ljudi borave i rade. Također, navedeni prostori često imaju slabu ventilaciju koja omogućava brzo razvijanje opasne atmosfere, osobito ako je prostor mali. Opasnosti nisu uvijek očite i mogu se izmijeniti od jednog do drugog ulaska u skučeni prostor. 
Svrha ovog rada je istražiti i analizirati opasnosti i štetnosti povezane s radom u skučenim prostorima.

Cilj rada je teorijski prikazati i opisati mjere i postupke za rad na siguran način u skučenim prostorima.

\section{METODOLOGIJA}

Metodologija rada obuhvaća uvodna razmatranja autora istaknutog problema istraživanja te se nastavlja istraživanjem pojmovnog određenja skučenog prostora nakon čega se pristupilo istraživanju opasnosti i štetnosti koje se javljaju pri radu u skučenom prostoru.

Problem istraživanja opisan je metodom deskripcije dok su prikupljeni podaci istraživani metodama analize, sinteze, komparacije i kompilacije.

\section{POJMOVNO ODREĐENJE SKUČENIH PROSTORA}

Europska agencija za zaštitu na radu (OSHA) definira skučeni prostor kao prostor koji:

- je dovoljno velik da radnik u njega može u potpunosti ući i obaviti posao

- nije dizajniran za stalan boravak radnika

- ima ograničenja pri ulasku ili izlasku

Britanski lzvršni odbor za zdravlje i sigurnost definira skučeni prostor kao takav ukoliko su ispunjeni sljedeći uvjeti:

- prostor mora biti zatvoren, ali ne nužno u cijelosti

- postoji prisutnost ili vjerojatnost nastanka jednog ili više rizika, primjerice povećan rizik od ozbiljnih ozljeda, gubitka svijesti, gušenja, utapanja itd.

Skučeni prostori mogu biti ispod ili iznad razine zemlje i mogu se naći na gotovo svakom mjestu rada. Skučeni prostor nije nužno mali prostor. Primjeri skučenih prostora su silosi, šahte, kanalizacija, cijevi, kamionske ili željezničke cisterne, krila zrakoplova, kotlovi, crpne stanice, digestori, jame, tankovi tereta na brodovima, tankovi pitke vode ili goriva, tankovi fekalija na brodovima, tankovi balasta, brodska dvodna itd. Jarci i rovovi također mogu biti skučeni prostori kada je pristup ili izlaz ograničen. 
Slika 1. Primjeri skučenih prostora

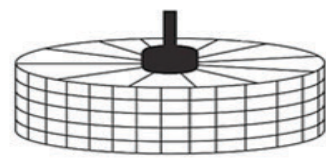

DIGESTOR
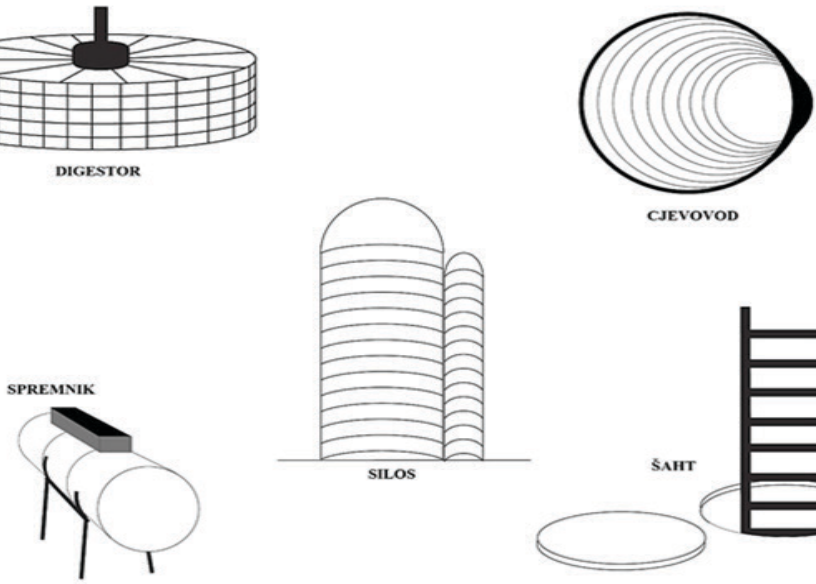

CJEVOVOD

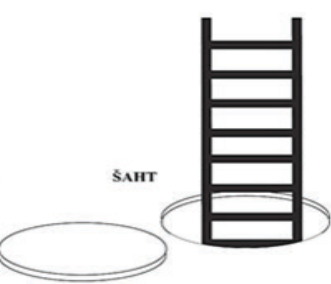

Izvor: prilagođeno prema

https://www.mhlnews.com/sites/mhlnews.com/files/uploads/2012/11/confinedexamples_1.jpg

Skučenim prostorom može se smatrati prostor u kojem je jedina opasnost otežan ulazak i izlazak iz prostora. Smatra se da je radnik „ušao" u skučeni prostor kada njegova zona disanja prelazi ravninu otvora za pristup prostoru. Primjeri skučenih prostora mogu uključivati potkrovlje zgrade, podzemne prostore i neke prostore za puzanje u zgradama.

Nadalje, skučenim prostorom može se smatrati i prostor u kojem dođe do promjene uvjeta rada. (www.open.alberta.ca, 30. 11. 2019.) Na primjer, prostor može imati sigurnu razinu kisika, ali posao koji treba obaviti to može promijeniti. Primjeri takvih radova i prostora su (www.hse.gov.uk, 30.11. 2019.):

- zavarivanje koje bi potrošilo dio kisika

- kabina za bojenje tijekom prskanja boje

- korištenje kemikalija za čišćenje koje mogu stvoriti toksičnu atmosferu

Primjerice, iskopani rov se ne smatra skučenim prostorom samo na temelju rizika od strukturnog urušavanja, ali će takav postati ako potencijalno sadrži štetne plinove, pare ili tvari u zraku u koncentracijama koje mogu uzrokovati oštećenje zdravlja, gubitak svijesti ili gušenje (www. safeworkaustralia.gov.au, 30. 11. 2019.).

U takvim se slučajevima prostor može definirati kao skučeni prostor za vrijeme trajanja tih radova, dok se ne postigne sigurna razina kisika ili dok se zagađivači ne otklone iz prostora (www.hse.gov. $u k, 30.11 .2019$.$) .$ 
Slika 2. Brodski tank tereta s upozorenjem opasnosti od smanjenja razine kisika

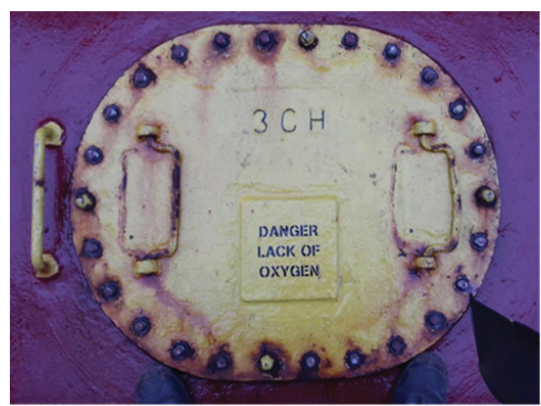

Izvor: izrada autora

\section{OPASNOSTIIŠTETNOSTI U SKUČENIM PROSTORIMA}

Najveće opasnosti u skučenim prostorima povezane su s atmosferskim uvjetima tih prostora. Atmosfera unutar različitih skučenih prostora varira ovisno o vrsti prostora, radovima koji se odvijaju unutar njega i onome što je u njima ranije bilo pohranjeno. Najučestalije opasnosti u skučenim prostorima mogu se razvrstati u (www.wshc.sg, 2. 12. 2019.):

- opasnost od gušenja - zbog nedostatka kisika

- opasnost od požara / eksplozije - zbog prisutnosti zapaljivih tvari

- opasnost od trovanja - zbog prisutnosti otrovnih tvari

\section{1 Opasnost od gušenja}

Zrak u našem prirodnom okruženju sadrži 20,9 \% kisika. Atmosferom sa smanjenim udjelom kisika smatra se atmosfera u kojoj je koncentracija kisika manja od 19,5\%. Niska razina kisika u skučenom prostoru može biti uzrokovana oksidacijom, hrđanjem, rastom bakterija, radom kao što je zavarivanje, plinsko rezanje itd. U kanalizaciji će prirodni proces oksidacije uslijed truljenja tvari iscrpiti kisik, što će rezultirati nedostatkom kisika. Smanjena razina kisika mogla bi se pojaviti i u skučenim prostorima sa slabom ventilacijom (www.wshc.sg, 2. 12. 2019.).

U tablici 1. prikazani su učinci i simptomi različitih razina kisika na čovjeka. 
Tablica 1. Učinci i simptomi različitih razina kisika na čovjeka

\begin{tabular}{|c|c|}
\hline Udio O2u zraku & Učinci i simptomi na čovjeka \\
\hline $\mathbf{1 9 , 5}$ & Minimalna razina za siguran ulazak \\
\hline $\mathbf{1 6 - 1 9}$ & Slaba koordinacija, umor \\
\hline $\mathbf{1 2}-\mathbf{1 6}$ & Ubrzan puls, otežano disanje \\
\hline $\mathbf{1 0 - 1 2}$ & Ubrzano i duboko disanje, plave usne, glavobolja \\
\hline $\mathbf{8 - 1 0}$ & Nesvjestica, mučnina, povraćanje \\
\hline $\mathbf{6 - 8}$ & Smrt za 8 minuta; u 50 \% slučajeva smrt za 6 minuta \\
\hline$<\mathbf{6}$ & Koma za 1 minutu, konvulzije, respiratorni i srčani zastoj, smrt \\
\hline
\end{tabular}

Izvor: prilagođeno prema Technical Advisory on Working Safely in Confined Spaces, 2010., str. 13, http://www.asmi.com/download.cfm?dobjid=285

Neke situacije mogu uzrokovati drastično smanjenje razine kisika što dovodi do atmosfere sa smanjenim udjelom kisika i mogućeg gušenja. To se može dogoditi u slučajevima kada:

- je kisik istisnut plinovima nastalim tijekom bioloških procesa (npr. metan u kanalizaciji),

- je kisik istisnut tijekom degazacije skučenog prostora inertnim plinom radi uklanjanja zapaljivih ili otrovnih para,

- je kisik iskorišten unutar metalnih spremnika i posuda kroz površinsku oksidaciju (npr. kada se formira hrđa),

- je kisik potrošen tijekom izgaranja zapaljivih tvari,

- se kisik apsorbira ili reagira sa žitaricama, drvnom sječkom, tlom ili kemikalijama u zatvorenim silosima.

Osim niskih razina kisika, radnici također mogu biti izloženi toksičnim tvarima kao što su dimovi, plinovi i pare tijekom rada unutar skučenog prostora. Ti zagađivači imaju granice profesionalne izloženosti na temelju svoje toksičnosti koje su u Republici Hrvatskoj definirane Pravilnikom o zaštiti radnika od izloženosti opasnim kemikalijama na radu, graničnim vrijednostima izloženosti i biološkim graničnim vrijednostima (N. N. br. 91/2018).

Istraživanja pokazuju kako postoji širok raspon toksičnih tvari koje mogu biti opasne u skučenim prostorima, ali većina smrtnih slučajeva nastala je uslijed nedostatka kisika ili povećane razine ugljičnog monoksida i sumporovodika (Selmanetal, 2018.).

Sumporovodik je plin koji nastaje u procesu razgradnje smeća i otpada u kanalizacijama. Jedan udisaj u atmosferi u kojoj se nalazi sumporovodik u koncentraciji od oko 500-700 ppm može biti smrtonosan. Niska razina sumporovodika ima karakterističan miris pokvarenih jaja, ali na oko 100 ppm drastično se smanjuje osjetilo mirisa i stvara lažan dojam da nema opasnosti. 
Ugljični monoksid vrlo je čest otrovan plin koji nema mirisa ni okusa, bistar je i bezbojan. Trovanje ugljičnim monoksidom može biti vrlo suptilno i može uzrokovati pospanost, kolaps i smrt (www. ihsa.ca, 2. 12. 2019.).

Opasnost od zatrpavanja ili ukopavanja znači da radnik može biti „progutan“ u materijalu što može dovesti do gušenja. Primjeri materijala koji mogu predstavljati opasnost od zatrpavanja su pijesak, tekućine, gnojivo, žito, ugljen, proizvodi od ugljena, leteći pepeo, stočna hrana itd.

Pohranjeni materijali kao što su pijesak i žito mogu stvoriti koru ili most kada se spremnik isprazni odozdo ostavljajući gornji sloj na mjestu. Radnici koji se kreću mostom ili rade ispod mosta na podu spremnika mogu biti zatrpani ukoliko se tako formirani most uruši (www.worksafe.qld.gov. $\mathrm{au}, 2.12 .2019$.).

\section{2 Opasnost od požara i eksplozije}

Opasnost od požara ili eksplozije u zatvorenom prostoru iznimno je visoka kad god se nakupe bilo koji zapaljivi plinovi i pare. Ako su plin ili para bezbojni i bez mirisa, nakupljanje se ne može otkriti bez korištenja instrumenata za detekciju plina. Da bi se zapaljivi plinovi i pare zapalili i doveli do požara ili eksplozije potrebno je zadovoljiti tri uvjeta, a to su goriva tvar, temperatura paljenja i kisik.

Zapaljiva atmosfera je atmosfera koja sadrži koncentraciju zapaljivih tvari u količini većoj od $10 \%$ od donje granice eksplozivnosti. Zapaljiva atmosfera u skučenim prostorima može biti posljedica isparavanja zapaljivih materijala koji se koriste u prostoru, kemijske reakcije kao što je stvaranje metana u kanalizaciji ili prisutnosti zapaljive prašine, poput one u silosima. Ukoliko se izvor zapaljenja, kao što je električni alat koji iskri, koristi u prostoru koji sadrži zapaljivu atmosferu, vjerojatno će doći do eksplozije. Eksploziju može izazvati i statički elektricitet (www.worksafe.qld. gov.au, 2. 12. 2019.).

„Granica zapaljivosti je područje koncentracija kod kojeg se smjesa zraka i zapaljivog materijala može nekim izvorom paljenja (iskrenjem, električnim lukom ilizagrijavanjem) zapaliti ili eksplodirati. Ovo područje se još naziva i područjem eksplozivnosti i ograničeno je donjom i gornjom granicom zapaljivosti." (www.glossary.periodni.com, 2. 12. 2019.).

Kada je koncentracija ispod donje granice eksplozivnosti (DGE) mješavina je previše siromašna, a kada je iznad gornje granice eksplozivnosti (GGE) mješavina je prebogata. Koncentracija plinova i para između DGE i GGE se naziva eksplozivnim opsegom ili područjem eksplozivnosti.

U slučaju zapaljivosti tekućina, zapaljiva smjesa pare / zraka može se generirati samo ako je temperatura okoline jednaka ili viša od temperature paljenja tekućine. Primjeri DGE i GGE vrijednosti za nekoliko zapaljivih tvari prikazane su u tablici 2. 
Tablica 2. Granice eksplozivnosti plinova i para

\begin{tabular}{|c|c|c|c|c|c|}
\hline \multirow{2}{*}{ medij } & \multicolumn{2}{|c|}{$\%$} & \multicolumn{2}{c|}{ g/m3 } & \\
\cline { 2 - 6 } & DGE & GGE & DGE & GGE & $\begin{array}{c}\text { gustoća u odnosu } \\
\text { na zrak }\end{array}$ \\
\hline metan & 5 & 15 & 33 & 400 & 0,554 \\
\hline etan & 3 & 15,5 & 37 & 195 & 1,049 \\
\hline propan & 2,1 & 9,5 & 39 & 180 & 1,562 \\
\hline amonijak & 15 & 28 & 105 & 200 & 0,597 \\
\hline ugljični monoksid & 12,5 & 74 & 145 & 870 & 0,967 \\
\hline metanol & 5,5 & 40 & 73 & 530 & 1,11 \\
\hline acetilen & 1,5 & 80 & 16 & 880 & 0,906 \\
\hline vodik & 4,0 & 75,6 & 3 & 64 & 0,069 \\
\hline
\end{tabular}

Izvor: prilagođeno prema: http://www.hkis.hr/upload/documents/ssu/predavanja/20120923\%20slavko\%20rumb akosnove\%20protueksplozijske\%20za\%C5\%A1tite_1\%20dio.pdf

\subsection{Opasnost od trovanja}

Otrovna atmosfera je atmosfera koja sadrži štetne tvari u koncentraciji većoj od granične vrijednosti izloženosti. Različite toksične tvari mogu biti prisutne u isto vrijeme u različitim vrstama zatvorenih prostora. Izlaganje toksičnim tvarima kao što su sumporovodik i ugljični monoksid može rezultirati smrću ili nepovratnim učincima na zdravlje (www.wshc.sg, 2.12.2019.).

Udisanje otrovnih plinova/para/prašina može djelovati na organizam na nekoliko načina (Uhlik, 2014:1230):

- nadražiti sluznice gornjih dišnih putova i dišnog sustava

- uzrokovati upalu/edem pluća

- utjecati na središnji živčani sustav

- uzrokovati gušenje.

Djelovanje na središnji živčani sustav manifestira se pojavom vrtoglavice i gubitkom ravnoteže. Pare nekih otapala mogu uzrokovati hipnotička stanja. U težim slučajevima posljedice mogu biti psihofizički poremećaji, npr. šok, nesvjestica (Uhlik, 2014:1230).

Plinovita tvar udisanjem dospije u krvotok, veže se na hemoglobin i tako sprječava prijenos kisika. To se još naziva i "kemijsko" gušenje, a na taj način djeluju npr. ugljikov monoksid i cijanovodik. Slično djeluju i neke kemijske tvari u krutom obliku ako u organizam dospiju gutanjem. Velika koncentracija, obično inertnog plina, smanjuje koncentraciju kisika u zraku i može prouzročiti gušenje zbog pomanjkanja kisika. Na taj način djeluju npr. ugljikov dioksid i dušik (Uhlik, 2014:1230). 
Različite toksične tvari imaju različite učinke na zdravlje pri različitim koncentracijama stoga je neophodno znati koje toksične tvari mogu biti prisutne u skučenim prostorima tako da se može ispravno postaviti odgovarajuća oprema za ispitivanje atmosfere, kao i odgovarajući alarm upozorenja prilikom detekcije opasne koncentracije nekog plina (www.wshc.sg, 2. 12. 2019.).

\section{4 Druge opasnosti i štetnosti}

Kontakt s mikroorganizmima, kao što su virusi, bakterije ili gljivice, može rezultirati infektivnim bolestima, dermatitisom ili plućnim bolestima. Kanalizacije, silosi za žitarice i jame za stajsko gnojivo su neki od primjera skučenih prostora gdje mogu biti prisutne biološke štetnosti (www. wshc.sg, 2. 12. 2019.).

Izlaganje mehaničkim opasnostima povezanim s proizvodnim procesima može rezultirati zaplitanjem, drobljenjem, rezanjem, probijanjem ili razdiranjem dijelova tijela osobe. Izvori mehaničkih opasnosti uključuju različite strojeve i uređaje kao što su miješalice ili drugi strojevi i uređaji s rotirajućim dijelovima kao što su zupčanici, remeni, osovine i tome slično. Mehaničke opasnosti prijete i od ručnih alata kojima se radi u skučenom prostoru, a to mogu biti brusilice, bušilice, pneumatski pištolji itd (www.wshc.sg, 2. 12. 2019.).

Česte su opasnosti od pada u dubinu ili pada predmeta na radnika. Skučeni prostori često su dizajnirani tako da nemaju sigurne površine za kretanje i imaju puno strukturalnih elemenata koji predstavljaju prepreke za kretanje. Osim toga, ukoliko se neki radovi izvode iznad neograđenog otvora za ulazak u skučeni prostor moguće je da alati ili dijelovi materijala upadnu unutra i ozlijede radnike koji rade u prostoru. Površine u skučenim prostorima često mogu biti masne ili mokre, kao što je to slučaj u tankovima ulja ili balasta, što povećava rizik od pokliznuća.

Opasnost od električne struje može uzrokovati ozljede zbog mogućnosti strujnog udara i/ili opeklina, a mogu nastati zbog kabela, transformatora, kondenzatora, izloženih priključaka i mokrih površina gdje se koristi električna oprema.

Priroda skučenog prostora je takva da lakše može dovesti do povećane vjerojatnosti kontakta kože s površinskim zagađivačima. Dodir kože s opasnim tvarima može rezultirati neposrednim zdravstvenim učincima kao što su opekotine, iritacije, alergijski dermatitis itd. (www.wshc.sg, 2.12.2019.).

Buka nastala uslijed procesa rada u skučenom prostoru može se pojačati zbog refleksije od tvrde površine. Izlaganje prekomjernoj buci može rezultirati gubitkom sluha, tinitusom i drugim štetnim učincima na zdravlje. Buka može spriječiti radnike da čuju signale upozorenja u slučaju opasnosti. Osim toga, konstanta buka može djelovati ometajuće na radnike i na taj način povećati rizik od ozljeda (www.wshc.sg, 2. 12. 2019.).

Opasnosti koje proizlaze iz ručno obavljanih radnih zadataka mogu se pogoršati zbog skučenosti prostora i ograničenjima vezanim za rad u takvom prostoru. Dodatne opasnosti mogu nastati zbog uporabe osobnih zaštitnih sredstava koja ograničavaju kretanje i hvat (www.wshc.sg, 2. 12. 2019.). 
Zračenje može imati štetan učinak na zdravlje izloženih radnika, a taj učinak ovisi o izvoru zračenja. Izvori zračenja uključuju radioaktivne izvore, rendgenske zrake, laser, bljesak zavarivanja, radiofrekvenciju i mikrovalove (www.wshc.sg, 2. 12. 2019.).

\section{RAD NA SIGURAN NAČIN U SKUČENIM PROSTORIMA}

Preduvjet za obavljanje poslova koji obuhvaćaju rad u skučenom prostoru jest taj da radnik prije svega mora biti osposobljen za rad u skučenom prostoru te upoznat sa opasnostima i štetnostima koje mu prijete prilikom obavljanja navedenog rada.

\section{1 Analiza i procjena rizika}

Prije svega, potrebno je analizirati i procijeniti rizike rada u skučenom prostoru. Prvi korak postupka za rad na siguran način vodi stručnjake sigurnosti kroz analizu karakteristika skučenog prostora. Analizom se istražuju karakteristike prostora, karakteristike zadatka i zahtjevi za reagiranje u izvanrednim situacijama.

Prva analiza uključuje analizu karakteristika skučenog prostora. Geometrijske karakteristike i atmosferske karakteristike skučenog prostora utječu na sigurnosne uvjete jer su takvi prostori ograničena područja s ograničenim otvorima za ulazak i izlazak. Posljedica toga je ograničeni protok zraka pa opasne tvari mogu stvoriti atmosferske uvjete koji su trenutno opasni po život ili zdravlje radnika.

Druga analiza istražuje karakteristike zadatka koji se obavlja u skučenom prostoru. Radna oprema i aktivnost koje se trebaju obaviti mogu utjecati na atmosferske uvjete. Konačno, treća analiza uključuje proučavanje zahtjeva za sigurne hitne operacije evakuacije i spašavanja. Analiza plana evakuacije i spašavanja u izvanrednim situacijama ima za cilj osigurati visoku učinkovitost u slučaju nesreće u skučenom prostoru (Botti et al., 2018.).

Identifikacija i procjena rizika za rad u skučenim prostorima složen je zadatak jer su gotovo uvijek prisutni višestruki rizici prilikom rada u takvom prostoru. Cilj je identificirati i procijeniti moguće uzroke ozljeda i nesreća u skučenim prostorima kako bi se utvrdile mjere za uklanjanje odnosno smanjivanje opasnosti, štetnosti i napora (Botti et al., 2018.).

\section{2 Dozvola za ulazak u skučeni prostor}

Nakon provedene analize i procjene rizika, potrebna je formalna provjera kako bi se osiguralo da su ispunjeni svi uvjeti za siguran ulazak i rad u skučenim prostorima. Nitko ne smije ući ili raditi u skučenom prostoru bez valjane dozvole. Također, dozvola predstavlja i jedan oblik komunikacije između voditelja radova, poslovođe, stručnjaka sigurnosti na radu i radnika te osigurava da su odgovorne osobe izvršile provjeru i odobrile ulazak i rad u skučeni prostor. (www.worksafe.qld.gov. au, 2. 12. 2019.). 
Preporučuje se da dozvola za ulazak u skučeni prostor jasno identificira uloge i odgovornosti osoba koje mogu odobriti određene poslove i koje su odgovorne za određivanje potrebnih sigurnosnih mjera (npr. izolacija, ispitivanja atmosfere, mjere u slučaju opasnosti).

Za rad u skučenim prostorima treba uspostaviti i provoditi sustav dozvola za rad i dozvola za ulazak u skučeni prostor. Implementacijom takvog sustava osigurava se da:

- se rad u zatvorenom prostoru provodi s pažljivim razmatranjem sigurnosti i zdravlja osoba koje obavljaju posao

- su osobe obaviještene o opasnostima povezanima s radom u zatvorenom prostoru

- su provedene potrebne sigurnosne mjere kada se obavlja rad u zatvorenom prostoru 
Slika 3. Primjerak dozvole za ulazak u skučeni prostor

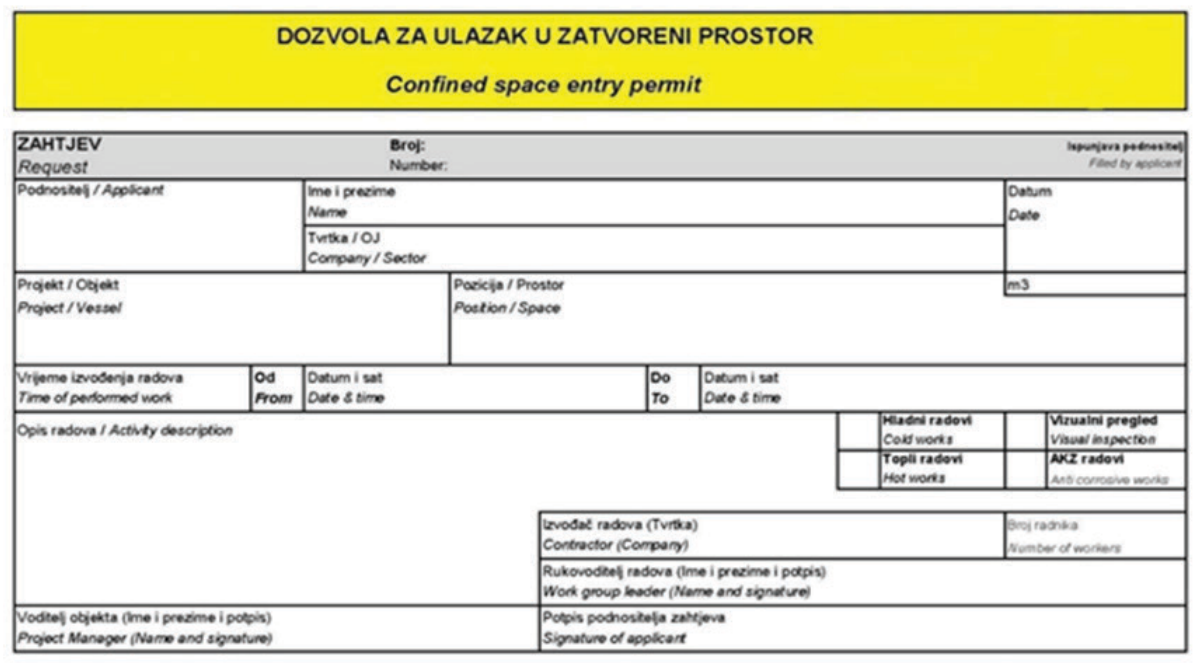

POTREBNE MUERE ZASTITE

Proventive measures

D ingrazis tokutine / Emply the Nids

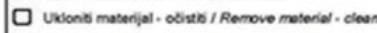

Donstantho ventirati / Conotanty vertilate

O Orads unz u provtox 1 Eamier anound the entrance

口 Ravipla v eSs innder $24 \mathrm{~V} / \mathrm{E} \times 24 \mathrm{~V}$ ighting

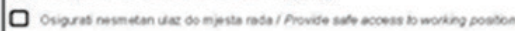

D Bindicis cjevorod / Seeled pipeline

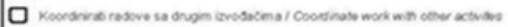

D Obarjesto rachike na drugim radovima / inform sumounding workers

D Radt sa preitidims / Work weth ahor browks

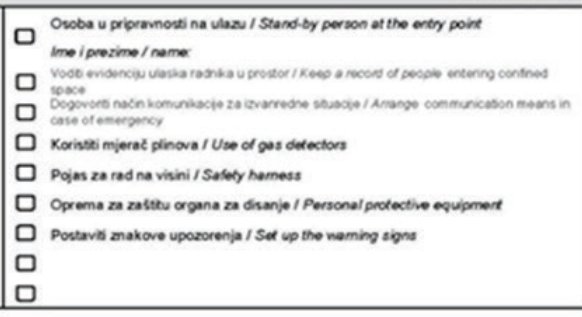

\begin{tabular}{|c|c|c|}
\hline $\begin{array}{l}\text { POTVRDA O PROVEDENIM MNERAMA } \\
\text { Confrmationof the implomentod moasures }\end{array}$ & \multicolumn{2}{|c|}{ 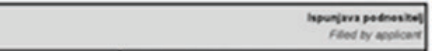 } \\
\hline 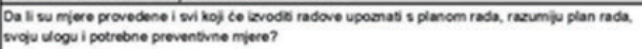 & 口 & $\begin{array}{l}\text { Patpis podnositela zahtivara } \\
\text { Signature of opplcant }\end{array}$ \\
\hline 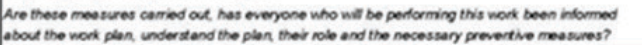 & 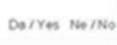 & \\
\hline
\end{tabular}

about the work plen. understand the plan theis nob and the necessary prevertive meosins?

\begin{tabular}{|c|c|c|c|c|c|}
\hline \multicolumn{5}{|c|}{\begin{tabular}{|l|} 
MUERENJA IISPITIVANJA ATMOSFERE \\
Measurement and analysis of the atmosphere
\end{tabular}} & \multirow{2}{*}{ 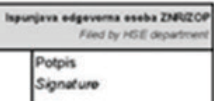 } \\
\hline 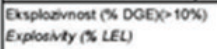 & $\begin{array}{l}\text { Udo kinka (19.5-23,5\%) } \\
\text { Oxpen laned (\$) }\end{array}$ & 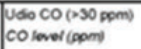 & $\begin{array}{l}\text { Outali plinovi } \\
\text { Oener gases }\end{array}$ & $\begin{array}{l}\text { Datum i sat } \\
\text { Dute and time }\end{array}$ & \\
\hline
\end{tabular}

\begin{tabular}{|c|c|c|c|}
\hline \multicolumn{3}{|c|}{$\begin{array}{l}\text { ODOBRENJE ZA ULAZAK U ZATVORENI PROSTOR } \\
\text { Permision to enty confined space }\end{array}$} & 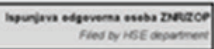 \\
\hline $\begin{array}{l}\text { iedao } \\
\text { iasued by }\end{array}$ & 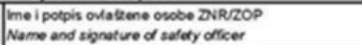 & $\begin{array}{l}\text { Dotum i sat } \\
\text { Dote s time }\end{array}$ & \\
\hline
\end{tabular}

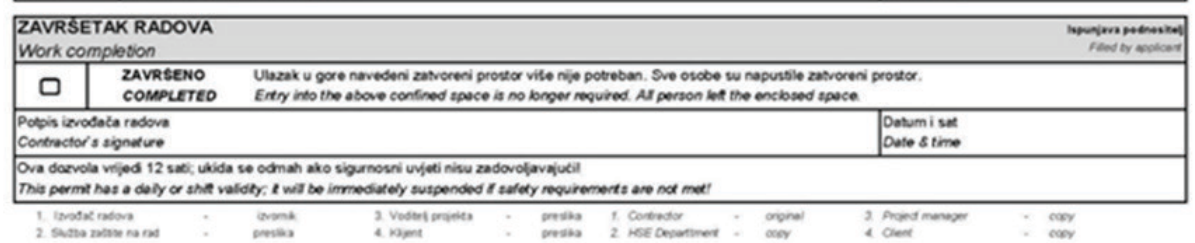

Izvor: Interna dokumentacija brodogradilišta Viktor Lenac 
Dozvola za ulazak u skučeni prostor treba sadržavati:

- identifikaciju i lokaciju skučenog prostora

- svrhu ulaska

- datum i vrijeme ulaska

- valjanost dozvole (datum i vrijeme završetka radova / isteka dozvole)

- potencijalne opasnosti i sigurnosne mjere

- ime osobe u pripravnosti na ulazu

- rezultate mjerenja atmosfere (kisik, zapaljivi plinovi, ostali otrovni plinovi)

- imena i potpise osobe u pripravnosti na ulazu, stručnjaka sigurnosti na radu, rukovoditelja radova, podnositelja zahtjeva.

\section{3 Ispitivanje atmosfere}

Nikada nije sigurno vjerovati osjetilima kada treba odrediti je li atmosfera u skučenom prostoru sigurna za disanje. Nedostatak kisika i prisutnost mnogih toksičnih ili zapaljivih plinova ne može se vidjeti, okusiti niti osjetiti. Važno je izvršiti ispitivanje atmosfere skučenih prostora kako bi se osiguralo da atmosfera bude sigurna za ulazak osoba.

Također je važno kontinuirano pratiti stanje atmosfere nakon ulaska kako bi se održala na sigurnoj razini (www.wshc.sg, 2. 12. 2019.).

Atmosferska ispitivanja potrebna su zbog procijene opasnosti u skučenom prostoru i provjere/ potvrde sigurnog ulaska u navedeni prostor. Nitko ne smije ući u skučeni prostor dok se ne utvrdi da je atmosfera unutar prostora sigurna. Ako je ulazak potreban, ovlašteni radnik mora biti opremljen odgovarajućim osobnim zaštitnim sredstvima (www.wshc.sg, 2. 12. 2019.).

Prilikom ispitivanja atmosfere u skučenom prostoru, važno je uzeti u obzir geometriju prostora i fizikalna svojstva plinova koji se mjere. Plinovi mogu biti na različitim razinama ili mjestima unutar skučenog prostora, ovisno o tome jesu li lakši ili teži od zraka.

Čak i kada je atmosfera u skučenom prostoru ispitana i ocijenjena kao sigurna za ulazak, barem jedan radnik u grupi koja radi u istoj okolini mora biti opremljen odgovarajućim instrumentom za mjerenje kisika, zapaljivih tvari i toksičnih tvari (www.wshc.sg, 2. 12. 2019.).

\subsection{Pročišćavanje, ventilacija i inertiranje zatvorenih prostora}

Kada je poznato da skučeni prostor sadrži opasne kontaminante, ključno je da se prostor pročisti na odgovarajući način prije svakog ulaska. Nakon toga treba osigurati kontinuiranu ventilaciju radi održavanja sigurnog radnog okruženja. Također je važno napomenuti da čišćenje i ventilacija ne isključuju potrebu za ispitivanjem atmosfere (www.wshc.sg, 2. 12. 2019.).

Pročišćavanje uključuje uklanjanje kontaminanata unutar skučenog prostora na način da se opasna atmosfera zamjeni neopasnom pomoću dovođenja zraka kako bi se postigla sigurna atmosfera. $\mathrm{Na}$ 
primjer, ako je skučeni prostor izvorno sadržavao otrovni plin, zrak bi trebalo upuhivati u prostor kako bi se smanjila koncentracija otrovnog plina na sigurnu razinu.

Pročišćavanje zraka unutar skučenog prostora provodi se prije svakog ulaska i svrha je uklanjanje bilo kojih postojećih kontaminanata zamjenom opasne atmosfere s drugim medijem kao što je zrak, voda, para ili inertni plin. Izbor prikladnog medija ovisit će o čimbenicima kao što su svojstva zagađivača i njihove koncentracije.

Nakon što su onečišćivači uklonjeni, skučeni prostor može se ventilirati. Ventilacija znači kontinuirano uvođenje svježeg zraka u prostor pomoću mehaničkih sredstava za održavanje prihvatljivih razina atmosfere. Prostor se mora ventilirati za vrijeme trajanja radova kako bi se održala prihvatljiva koncentracija kisika, osigurala zaštita u slučaju slučajnog ispuštanja kemikalija, uklonili kontaminanti nastali obavljenim radom ili kako bi se prostor ohladio (www.labour.gov. on.ca, 4. 12. 2019.).

Ventilacija uključuje istiskivanje zraka i uvođenje svježeg zraka ili kontinuirano uklanjanje kontaminanata lokalnom ispušnom ventilacijom na izvoru zagađenja, primjerice zavarivanja.

Kako bi se osigurala odgovarajuća ventilacija, mjesta dovoda zraka i ispušnih plinova treba što je moguće više odvojiti. Čisti kisik ne smije se koristiti za ventilaciju skučenog prostora (www.labour. gov.on.ca, 4. 12. 2019.).

Inertiranje je poseban oblik pročišćavanja i ventilacije. Inertiranje uključuje smanjivanje razine kisika unutar skučenog prostora pomoću inertnog plina kao što je dušik, ugljični dioksid ili argon kako bi se uklonila opasnost od požara ili eksplozije. Koncentracija kisika se smanjuje ispod razine koja može podržati izgaranje. Nakon inertiranja konstantno se prati koncentracija kisika i skučeni prostor može se ventilirati pomoću inertnog plina kako bi se osiguralo da se koncentracija kisika ne povećava. Inertni plinovi stvorit će nesigurnu atmosferu (nedostatak kisika) i stoga radnici koji ulaze u skučeni prostor trebaju koristiti odgovarajuće izolacijske respiratore (www.labour.gov. on.ca, 4. 12. 2019.).

Zbog jedinstvenih karakteristika skučenih prostora, prirodna ventilacija obično nije adekvatna i zahtijeva uporabu mehaničke ventilacije koja može biti prisilna ventilacija ili lokalna ispušna ventilacija.

Pri određivanju vrste ventilacije u obzir se uzimaju svojstva kontaminanata, konfiguracija prostora i očekivani rad koji će se obaviti u skučenom prostoru.

\subsection{Prisilna ventilacija}

Prisilna ventilacija dovodi svježi zrak u skučeni prostor upotrebom mehaničkih uređaja za kretanje zraka, poput puhala. Stalna opskrba svježim zrakom u dovoljnoj količini pomoći će održati razinu kisika u prostoru unutar sigurnog raspona, kao i razrijediti razinu opasnih ili otrovnih tvari koje se oslobađaju u skučenom prostoru (www.wshc.sg, 2. 12. 2019.). 
Važno je osigurati da se uređaj za dovođenje zraka postavi tamo gdje je zrak koji se uvlači u skučeni prostor čist. Na primjer, nije prikladno smjestiti uređaj za dovođenje zraka iza dizel generatora gdje ispušni plinovi iz generatora mogu ući u skučeni prostor (www.wshc.sg, 2. 12. 2019.).

U nekim slučajevima, skučeni prostori mogu biti ispunjeni zapaljivim plinovima i parama, osobito ako je izvorna koncentracija zapaljivih iznad GGE. Ventilacijom sa svježim zrakom, koncentracija tih tvari može se dovesti unutar područja eksplozivnosti. Tada treba razmotriti korištenje lokalne ispušne ventilacije ili inertiranje medijem kao što je dušik (www.wshc.sg, 2. 12. 2019.).

Slika 4. Primjer uređaja za prisilnu ventilaciju

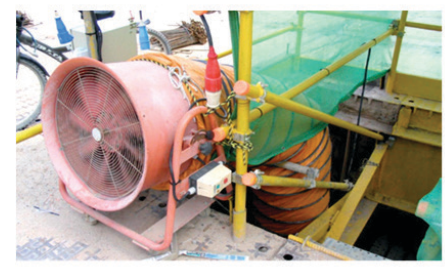

Izvor: Technical Advisory on Working Safely in Confined Spaces, 2010., str. 44, http://www.asmi.com/download.cfm?dobjid=285

\subsubsection{Lokalna ispušna ventilacija}

Ispušna ventilacija se postiže izvlačenjem zraka iz skučenog prostora, a tim procesom se uklanjaju zagađivači iz prostora. Lokalna ispušna ventilacija specifična je primjena ispušne ventilacije gdje se izvlačenje primjenjuje izravno na izvoru onečišćenja (www.wshc.sg, 2. 12. 2019.).

Korištenje lokalne ispušne ventilacije treba uzeti u obzir kada prisilna ventilacija nije učinkovita zbog ograničenja u skučenom prostoru ili kada se tijekom rada mogu pojaviti visoke koncentracije kontaminanata zbog postupka kao što su zavarivanje, nanošenje antikorozivnih premaza ili korištenje kemijskih sredstava za čišćenje (www.wshc.sg, 2. 12. 2019.).

Da bi lokalna ispušna ventilacija bila učinkovita, ključno je postaviti usisni dio cijevi blizu izvora onečišćenja. Osim toga, važno je da je kapacitet ventilatora dovoljan za potrebe osiguravanja sigurne atmosfere s obzirom na konfiguraciju prostora i prirodu obavljanog posla (www.wshc.sg, 2. 12. 2019.).

\subsection{3 "Push-pull" sustav ventilacije}

Obzirom da lokalna ispušna ventilacija izvlačenjem zraka iz prostora stvara neznatan negativan tlak u prostoru, važno je da se zamjenski zrak osigurava u obliku dovodne ventilacije. Sustav "push-pull" koristi kombinaciju prisilne ventilacije i lokalne ispušne ventilacije i na taj način uvodi svježi zrak u prostor istovremeno izvlačeći onečišćeni zrak iz prostora. Ovakav sustav ventilacije obično pruža učinkovitiju ventilaciju skučenog prostora nego što bi to bilo samo korištenjem jednog sustava ventilacije i preporučuje se kad god je to izvedivo (www.wshc.sg, 2. 12. 2019.). 
Slika 5. Primjer "push-pull" sustava ventilacije

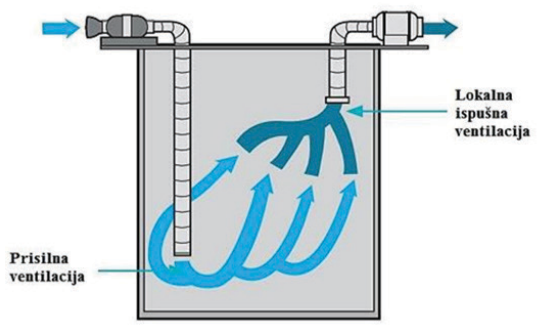

Izvor: Technical Advisory on Working Safely in Confined Spaces, 2010., str. 46, http://www.asmi.com/download.cfm?dobjid=285

\section{5 Rasvjeta u skučenim prostorima}

Za ulazak i rad u skučenom prostoru potrebno je osigurati odgovarajuću i prikladnu rasvjetu. Pristup i prolaz u prostor mora imati osvjetljenje od najmanje 50 lux-a. Sva prijenosna ručna rasvjeta koja se nalazi u skučenim prostorima mora raditi pod naponom koji ne prelazi $55 \mathrm{~V}$ izmjenične struje ili $110 \mathrm{~V}$ istosmjerne struje (www.wshc.sg, 2. 12. 2019.).

Takva protueksplozijska rasvjeta radi obično pod naponom od $24 \mathrm{~V}$ ili $12 \mathrm{~V}$, a ponekad i nižem. Protueksplozijske svjetiljke imaju smanjen rizik od izazivanja eksplozije jer njihova konstrukcija izolira iskre unutar jedinice čime se sprječava da svjetiljka postane izvor zapaljenja. Osim toga, robusno kućište djeluje kao dodatna zaštita (www.larsonelectronics.com, 4. 12. 2019.)

Specijalna rasvjetna tijela strogo su regulirana OSHA-om radi njihove sposobnosti da smanje intenzitet strujnog udara. Korištenjem protueksplozijske rasvjete niskog napona povećavaju se šanse za preživljavanje pri kontaktu s električnom komponentom. Udar iz niskonaponskog rasvjetnog tijela može izbaciti radnika iz ravnoteže, ali mu neće uzrokovati ozbiljne opekline i nekontrolirano potresanje koje bi lako moglo dovesti do ozbiljnih ozljeda ili smrti (www. larsonelectronics.com, 4. 12. 2019.).

\subsection{Evakuacija i spašavanje}

Prije nego što je bilo tko ovlašten ući u skučeni prostor, ključno je imati na raspolaganju osposobljeno osoblje za izvanredne situacije kada radnik treba pomoć. Važno je da takvo osoblje odmah dođe do lokacije i zna kako se nositi s hitnim slučajevima. Svako neplanirano spašavanje, kao kad netko instinktivno uđe u skučeni prostor da pomogne unesrećenom kolegi, može dovesti do dvostrukog smrtnog slučaja (www.wshc.sg, 2. 12. 2019.).

Obaveza je imati pisani plan i uspostavljeni sustav spašavanja na licu mjesta koji uključuje opremu, uređaje za izvlačenje unesrećenika, uređaje za disanje i reanimaciju. Težina nesreće može se smanjiti pravovremenim upozorenjima od strane osobe u pripravnosti koja se nalazi izvan skučenog prostora. Dobro obučeni i potpuno opremljeni spasilački tim može osigurati brzu reakciju u hitnim 
slučajevima. Pisani plan spašavanja uspostavlja se u svrhu spašavanja osoba iz skučenog prostora. Plan akcije spašavanja mora sadržavati imena spasilačkog osoblja, metode spašavanja kako bi se izvukle osobe iz zatvorenog prostora, propisanu vrstu opreme potrebne za spašavanje i dostupnost iste te sredstva za pravovremeno pozivanje imenovanog spasioca (www.wshc.sg, 2. 12. 2019.).

Procjena rizika će odrediti koje su metode spašavanja potrebne. Metode spašavanje ovisit će o prirodi skučenog prostora, utvrđenim rizicima i vrstama hitnih situacija koje se mogu predvidjeti. Važno je uočiti moguće izvanredne situacije u skučenom prostoru, te bilo koju drugu predvidivu nesreću za uspješno provođenje operacije spašavanja (www.wshc.sg, 2. 12. 2019.).

\section{ZAKLJUČAK}

Skučeni prostori nisu namijenjeni za rad i boravak ljudi i mogu biti vrlo opasni. Rad u navedenim prostorima predstavlja visokorizičnu aktivnost pa je provođenje mjera zaštite na radu od ključne važnosti za očuvanje zdravlja i sigurnosti svih radnika koji ulaze i rade u takvim prostorima.

Najveće opasnosti u skučenim prostorima povezane su $s$ atmosferskim uvjetima tih prostora. Atmosfera unutar različitih zatvorenih prostora ovisi o vrsti prostora, radovima koji se unutra odvijaju i onome što je u njima ranije bilo pohranjeno. Najučestalije opasnosti u skučenim prostorima su opasnost od gušenja, opasnost od požara i/ili eksplozije i opasnost od trovanja.

Stoga je vrlo važno kao prvi korak izvršiti analizu samog prostora kako bi se mogle prepoznati sve opasnosti i štetnosti koje prijete prilikom rada u skučenom prostoru. Na osnovu izvršene analize, slijedeći korak izrada je adekvatne procjene rizika koja će biti temelj za određivanje mjera sigurnosti kako bi se utvrđeni rizik uklonio.

Ono što je vrlo bitno u čitavom procesu jest izdavanje dozvole za ulazak u skučeni prostor nakon što se utvrdi da su izvršene sve propisane mjere sigurnosti i da je sam prostor kao takav siguran za obavljanje predviđenog rada. Sustav dozvola za ulazak u skučene prostore osigurava komunikaciju između ovlaštenih i odgovornih osoba za izvršenje određenog rada u takvom prostoru. Rizik rada u skučenom prostoru može se smanjiti adekvatnom procjenom rizika i provedbom propisanih mjera sigurnosti.

\section{LITERATURA}

Confined Spaces, https://www.ihsa.ca/pdfs/safety_manual/Confined_Spaces.pdf (2.12.2019.)

Botti, L. et al. (2018) "An integrated holistic approach to health and safety in confined spaces", Journal of Loss Prevention in the Process Industries, 55, pp. 25-35. https://doi.org/10.1016/j.jlp.2018.05.013

Granica zapaljivosti, https://glossary.periodni.com/glosar.php?hr=granica+zapaljivosti (2.12.2019.)

Guideline for Developing a Code of Practice for Confined Space Entry,

https://ohs-pubstore.labour.alberta.ca/download/sample/154 (30.11.2019.)

HSE, Safe work in confined spaces, Approved Code of Practice and guidance, 2014., http://www.hse.gov.uk/pubns/ priced/l101.pdf (30.11.2019.)

Selmanetal, J., An investigation into the rate and mechanism of incident of work-related confined space fatalities, Safety Science 109, 2018., str. 333-343 
Low Voltage Lights for Confined Spaces and Wet Locations, https://www.larsonelectronics.com/blog/2017/01/10/ confined-space/low-voltage-lights-confined-spaces-wet-locations (4.12.2019.)

Pravilnik o zaštiti radnika od izloženosti opasnim kemikalijama na radu, graničnim vrijednostima izloženosti i biološkim graničnim vrijednostima, NN 91/2018,

https://narodne-novine.nn.hr/clanci/sluzbeni/full/2018_10_91_1774.html (2.12.2019.)

Safe Work Australia, Confined spaces - Code of Practice, 2018.,

https://www.safeworkaustralia.gov.au/system/files/documents/1810/modelcopconfined_spaces.pdf (30.11.2019.)

Uhlik Branko, Požarno opasne, toksične i reaktivne tvari, Kem. Ind. 63 (5-6),1229-1231, 2014.,

https://hrcak.srce.hr/file/178534 (2.12.2019.)

Workplace Health and Safety Queensland, Confined spaces: Code of Practice, 2011.,

https://www.worksafe.qld.gov.au/_data/assets/pdf_file/0010/58159/Confined-spaces-COP-2011.pdf

(2.12.2019.)

WSH COUNCIL (Workplace Safety and Health Council): Technical Advisory on Working Safely in Confined Spaces, 2010., https://www.wshc.sg/files/wshc/upload/cms/file/2014/cs2.pdf (2.12.2019.) 


\title{
SAFE WORK IN CONFINED SPACES
}

\section{Kristina Dundović}

MEng, Lecturer, Polytechnic of Rijeka, Vukovarska 58, 51000 Rijeka, Croatia; e-mail: kdundovic@veleri.hr

\section{Stela Stašić}

Professional Specialist Engineer of Safety and Protection, Occupational Health And Safety, Viktor Lenac d. d., Martinšćica bb, P. O. box 210, 51000 Rijeka, Croatia; e-mail: stelastasic@gmail.com

\begin{abstract}
A confined space can be defined as a space large enough for a worker to fully enter in it and do the work, as a space that is not designed for permanent residence of workers and has restrictions on entry or exit. The greatest hazards in confined spaces are related to the atmospheric conditions of those spaces. The atmosphere inside the confined spaces depends on the type of the space, the work that is taking place inside and on what has previously been stored there. The most common hazards in confined spaces are the risk of suffocation, the risk of fire and / or explosion and the risk of poisoning. Work in confined spaces is a high-risk activity, so the implementation of occupational safety measures is crucial for maintaining the health and safety of all workers who enter and work in such spaces.
\end{abstract}

Key words: occupational safety measures, hazards, confined spaces 